\title{
Neuroendocrine pathways mediating nutritional acceleration of puberty: insights from ruminant models
}

\author{
Marcel Amstalden ${ }^{1}$ *, Bruna R. C. Alves ${ }^{1}$, Songrui Liu ${ }^{1}$, Rodolfo C. Cardoso ${ }^{1,2}$ and Gary L. Williams ${ }^{1,2}$ \\ ${ }^{1}$ Department of Animal Science, Texas A\&M University, College Station, TX, USA \\ ${ }^{2}$ Animal Reproduction Laboratory, Texas AgriLife Research, Beeville, TX, USA
}

\section{Edited by:}

Carol F. Elias, University of Texas

Southwestern Medical Center, USA

\section{Reviewed by:}

Raul Miguel Luque Huertas, University of Codoba, Spain

Licio A. Velloso, University of

Campinas, Brazil

${ }^{*}$ Correspondence:

Marcel Amstalden, Department of

Animal Science, Texas A\&M

University, 2471 TAMU, College

Station, TX 77845-2471, USA.

e-mail:m.amstalden@tamu.edu

\begin{abstract}
The pubertal process is characterized by an activation of physiological events within the hypothalamic-adenohypophyseal-gonadal axis which culminate in reproductive competence. Excessive weight gain and adiposity during the juvenile period is associated with accelerated onset of puberty in females. The mechanisms and pathways by which excess energy balance advances puberty are unclear, but appear to involve an early escape from estradiol negative feedback and early initiation of high-frequency episodic gonadotropinreleasing hormone $(\mathrm{GnRH})$ secretion. Hypothalamic neurons, particularly neuropeptide $Y$ and proopiomelanocortin neurons are likely important components of the pathway sensing and transmitting metabolic information to the control of $\mathrm{GnRH}$ secretion. Kisspeptin neurons may also have a role as effector neurons integrating metabolic and gonadal steroid feedback effects on GnRH secretion at the time of puberty. Recent studies indicate that leptin-responsive neurons within the ventral premammillary nucleus play a critical role in pubertal progression and challenge the relevance of kisspeptin neurons in this process. Nevertheless, the nutritional control of puberty is likely to involve an integration of major sensor and effector pathways that interact with modulatory circuitries for a fine control of $\mathrm{GnRH}$ neuron function. In this review, observations made in ruminant species are emphasized for a comparative perspective.
\end{abstract}

\section{Keywords: GnRH, kisspeptin, leptin, NPY, POMC}

\section{INTRODUCTION}

Pubertal development involves physical and behavioral changes that are linked to the activation of the hypothalamicadenohypophyseal-gonadal axis (Sisk and Foster, 2004). The progression of events is controlled largely by genetic and environmental factors, among which nutrition has a major influence. Historically, most studies investigating the effects of nutrition on pubertal development have used models that represent states of nutrient or metabolic insufficiency (Foster and Olster, 1985; Manning and Bronson, 1989; Suttie et al., 1991). However, evidence that excessive weight gain and adiposity during childhood are associated with early onset of puberty in girls (Lee et al., 2007; Jasik and Lustig, 2008; Rosenfield et al., 2009), and indications that precocious puberty is associated with increased risks for development of polycystic ovarian syndrome, reproductive cancers, and psychological distress (Golub et al., 2008) has renewed interest in understanding the mechanisms by which nutrient sufficiency supports reproductive maturation.

Signals mediating nutritional and metabolic information are perceived largely at the level of the hypothalamus (Schneider, 2004) and are likely integrated in structural and cellular networks that control various neuroendocrine functions, including puberty. Although common mechanisms exist, functional differences among mammalian species add complexity to the ability to extrapolate observations made in distinct animal models. In the current review, we have focused the discussion on neuroendocrine pathways known to regulate the onset of puberty in ruminant species. Domestic ruminants have been used extensively as animal models in neuroendocrine research and the ability to effectively measure the temporal release of hypothalamic neuropeptides in these species is a particularly relevant feature. In this review, an overview of recent studies investigating the influence of elevated body weight gain during the juvenile period on timing the onset of puberty in ewe lambs and heifers is presented.

\section{PUBERTY AS A NEUROENDOCRINE EVENT}

The onset of puberty in females is characterized by an activation of the hypothalamic-adenohypophyseal-gonadal axis that precedes the establishment of cyclic ovarian activity. The peripubertal increase in pulsatile release of gonadotropin-releasing hormone $(\mathrm{GnRH})$ and luteinizing hormone ( $\mathrm{LH})$ supports final maturation of ovarian follicles and enhances ovarian steroidogenesis (Kinder et al., 1987). Elevated circulating concentrations of estradiol induce the preovulatory surge of $\mathrm{GnRH} / \mathrm{LH}$, which leads to first ovulation. During most of the juvenile period, the hypothalamicadenohypophyseal-gonadal axis remains relatively quiescent, and the frequency of LH release is low (Foster and Jackson, 2006; Plant and Witchel, 2006). A major limiting factor for increased secretion of LH and development of preovulatory follicles during the juvenile period is the lack of appropriate stimulation of the gonadotropes by $\mathrm{GnRH}$. This assertion is supported by the observation that ovarian function is stimulated in immature female monkeys treated with GnRH (Wildt et al., 1980), and in lambs treated with LH (Foster et al., 1984). Because estradiol can lead to a 
surge-like release of LH in prepubertal females (Foster and Karsch, 1975; Andrews and Ojeda, 1977), it is believed that the estradiol positive feedback is functional before reproductive maturation is established. However, the lack of an appropriate stimulatory signal that sustains elevated GnRH neuronal activity necessary for continued ovarian function, or the presence of inhibitory signals that restrain GnRH neuronal activity, may explain the infrequent release of $\mathrm{GnRH}$ characteristic of the prepubertal period.

Increased sensitivity to estradiol negative feedback contributes to the inhibition of GnRH release in ewe lambs and heifers (Foster and Ryan, 1979; Day et al., 1984). The ability of low circulating concentrations of estradiol to inhibit the pulsatile release of LH is diminished during maturation, and frequency of $\mathrm{LH}$ pulses increases (Ebling et al., 1990). In primates, the frequency of episodic release of LH is low during a substantial portion of the juvenile period independent of gonadal influence (Pohl et al., 1995). However, estradiol-dependent maintenance of low gonadotropin secretion becomes relevant later during juvenile development (Pohl et al., 1995), and changes in estradiol negative feedback seem to also play a role in the establishment of heightened frequency of LH release in primates.

\section{METABOLIC-SENSING PATHWAYS MEDIATING THE NUTRITIONAL CONTROL OF PUBERTAL DEVELOPMENT}

Adequate growth and adiposity are critical for normal progression of puberty in mammals. Growth restriction (Foster and Olster, 1985; Suttie et al., 1991) and excessive exercise (Manning and Bronson, 1989; Malina, 1994) during the juvenile period delay puberty, likely by decreasing the release of GnRH (I'Anson et al., 2000) in association with heightened negative feedback sensitivity to estradiol (Foster and Olster, 1985). In contrast, increased adiposity seems to facilitate reproductive maturation and advance the onset of puberty (Kaplowitz et al., 2001; Lee et al., 2007; Rosenfield et al., 2009). In cattle, a high proportion of heifers fed to gain weight at high rates during the juvenile period exhibit precocious puberty (Gasser et al., 2006a,b). This occurrence is associated with attenuation of estradiol negative feedback and increased pulsatile release of LH (Gasser et al., 2006a). Therefore, nutritional cues interact with gonadal steroid feedback to time the onset of puberty in females.

Studies investigating adiposity and adipocyte-derived hormones as essential factors for the initiation of puberty have revealed that leptin, a hormone secreted predominantly by adipocytes, has a critical role for the progression of puberty in various species, including ruminants (Zieba et al., 2005). Although leptin does not affect secretion of $\mathrm{LH}$ in adequately fed ewes (Henry et al., 1999) and cows (Amstalden et al., 2002), leptin prevents fasting-induced reduction in LH pulsatility in prepubertal heifers (Maciel et al., 2004). Because in mice GnRH neurons are not affected by leptin directly (Quennell et al., 2009), leptin's actions on GnRH/LH release in ruminants are likely mediated by intermediate pathways. In addition to leptin, information from other hormones (e.g., insulin and ghrelin) and nutrients (e.g., glucose, fatty acids, and amino acids) is also likely to be integrated in a complex neural network that perceive and signal availability of metabolic fuels to the control of reproductive function (Schneider, 2004).
Critical neuronal pathways mediating signals of nutrient sufficiency and insufficiency have been identified. Hypothalamic neuropeptide Y (NPY)/agouti-related protein (AgRP) neurons, and proopiomelanocortin (POMC) neurons are considered major pathways by which nutritional signals are effected (Crown et al., 2007). These populations of neurons in the arcuate nucleus express the leptin receptor and are responsive to changes in nutritional status (Kalra and Kalra, 2003). Specifically, NPY has been shown to mediate the inhibitory effects of undernutrition on reproductive function (Kalra and Crowley, 1984). Contrary to rats in which NPY has both stimulatory and inhibitory effects on LH release depending on gonadal steroid milieu (Sahu et al., 1987), NPY has a predominant inhibitory action on the release of $\mathrm{LH}$ in ruminants in the presence and absence of estradiol (Gazal et al., 1998; Estrada et al., 2003; Morrison et al., 2003). This effect of NPY has been shown to be largely due to inhibition of GnRH release (Gazal et al., 1998) and may be mediated by direct NPY actions on GnRH neurons (Klenke et al., 2010).

Intact juvenile female rats chronically exposed to NPY exhibit delayed sexual maturation (Catzeflies et al., 1993), and this effect may be mediated by the Y1 receptor (El Majdoubi et al., 2000; Pralong et al., 2000). Such observations indicate that a break in NPY inhibition may be critical for the peripubertal initiation of high-frequency, episodic release of GnRH. It is unclear, however, whether increased growth and adiposity during the juvenile period has an impact on NPY restraint of GnRH release. The number of NPY neurons and NPY content in the arcuate nucleus of male, juvenile rats reared in small litters to promote over nutrition does not differ from those of rats reared in normal-size litters (Plagemann et al., 1999). We recently began to investigate the role of hypothalamic NPY circuitry in controlling early onset of puberty in an animal model in which elevated body weight gain during the juvenile period accelerates puberty (Gasser et al., 2006a,b). In juvenile heifers that gained body weight at a high rate between 4 and 6.5 months of age, the expression of NPY in the arcuate nucleus was decreased compared to heifers that gained weight at lower rates (Allen et al., 2009). Using a similar dietary treatment, we also observed that the proportion of GnRH neurons in close proximity to NPY fibers in the preoptic area and hypothalamus was reduced in heifers gaining body weight at high rates (Alves et al., 2011). Interestingly, these structural changes in the NPY circuitry seem to be more evident in GnRH neurons located in the mediobasal hypothalamus. In this region, the proportion of GnRH neurons highly innervated by NPY fibers was reduced by $\sim 50 \%$ in heifers gaining weight at high rates (Alves et al., 2011). It is important to note that both groups of heifers were in positive nutrient balance and had nutrient requirements for growth met, except that they differed in the target rate of gain. In mice, there is evidence that neural projections originating in the arcuate nucleus are regulated by leptin during early postnatal development (Bouret et al., 2004a), and that changes observed in leptin-sensitive hypothalamic neurocircuitry may involve NPY neurons (Bouret et al., 2004b). Therefore, structural and functional changes involving hypothalamic NPY circuitry during the early juvenile period may be involved in the mechanisms by which excessive nutrition and adiposity support early onset of puberty. 
The melanocortin system is also considered to have an important role in mediating the neuroendocrine control of metabolism and reproductive function (Schneider, 2004). Melanocytestimulating hormone alpha $(\alpha-\mathrm{MSH})$, one of the products of the proopiomelanocortin $(P O M C)$ gene in the hypothalamus, is considered a primary effector. Leptin stimulates the expression of POMC mRNA in mice, rats and sheep (Schwartz et al., 1997; Backholer et al., 2010), and a melanocortin receptor agonist (MTII) stimulates LH release in undernourished, ovariectomized, hypogonadotropic ewes (Backholer et al., 2010). The effects of melanocortins in stimulating hypothalamic-hypophyseal function seem to be mediated primarily by the melanocortin receptor type 4 (MC-4) because a MC-4 selective antagonist blocked the leptin-induced LH release in fasted rats (Watanobe et al., 1999). Although MC-4 is expressed in GT1-1 cells, a GnRH-secreting cell line (Khong et al., 2001), it is unclear whether GnRH neurons contain melanocortin receptor. Nevertheless, the endogenous antagonist of melanocortin receptors, AgRP, has also been demonstrated to alter gonadotropin release. In ovariectomized, estradiol, and progesterone-primed rats, AgRP abolishes the LH surge (Schioth et al., 2001), and in ovariectomized, adult rhesus monkeys, administration of AgRP suppresses episodic LH release (Vulliémoz et al., 2005).

Agouti-related protein and NPY are co-expressed in neurons within the arcuate nucleus (Broberger et al., 1998), and leptin treatment decreases expression of NPY and AGRP in the arcuate nucleus of adult rats (Ahima et al., 1999). Interestingly, leptin was ineffective in regulating $N P Y$ and $A G R P$ expression in neonatal mice (Ahima and Hileman, 2000), indicating that leptin's effect on expression of those genes may be developmentally regulated. However, leptin appears to be critical for development of hypothalamic neuronal projections during the early postnatal period in mice and rats (Bouret et al., 2004a, 2008), and activates POMC neurons in the arcuate nucleus early during the postnatal period in mice (Bouret et al., 2004b). In our studies in prepubertal heifers, AGRP mRNA abundance in the hypothalamus was lower in heifers that gained body weight at high rates during the juvenile period (Allen et al., 2009). In contrast, POMC mRNA abundance in the arcuate nucleus was increased in heifers gaining weight at high rates (Allen et al., unpublished). Interestingly, these changes in gene expression were associated with an increase in circulating concentrations of leptin in heifers gaining weight at high rates (Allen et al., 2009; Alves et al., 2011).

In a study using hypothalamic tissue from non-human primates and rats, Roth et al. (2007) suggested that a network of genes involved in a range of cellular functions, including control of transcription and cellular metabolism, is activated at the time of puberty. In a recent study using microarray technology to investigate changes in gene expression in the arcuate nucleus of prepubertal heifers fed to gain weight at high or low rates, we observed that genes involved in a variety of biological functions are responsive to nutritional input during the juvenile period (Allen et al., unpublished). Differentially-regulated genes included those associated with regulation of cellular metabolic processes, receptor and intracellular signaling, and neuronal communication. Therefore, the prepubertal, growing female seems exquisitely sensitive to nutrient inputs because changes in the regulation of metabolic-sensing and effector pathways are in tune for the fine control of neuroendocrine functions. Mechanisms involved may include regulation of gene expression, control of cellular functions, and plasticity of functional structures within the hypothalamus.

\section{ROLE OF KISSPEPTIN IN MEDIATING NUTRITIONAL ACCELERATION OF ONSET OF PUBERTY}

Observations that mutations in the kisspeptin receptor result in hypogonadotropic hypogonadism in humans (de Roux et al., 2003; Seminara et al., 2003) has implicated kisspeptin in the control of reproductive function. In mice, dysfunction of kisspeptin receptor leads to decreased gonadal development and impairment in timing of pubertal onset (de Roux et al., 2003; Seminara et al., 2003). Actions of kisspeptin on regulation of reproductive functions appear to be mainly by its direct effects on GnRH release (Caraty et al., 2007). Kisspeptin is a potent stimulator of LH secretion in mature (Caraty et al., 2007) and prepubertal females (Navarro et al., 2004; Kadokawa et al., 2008; Redmond et al., 2011a). In prepubertal rats, kisspeptin treatment induces early vaginal canalization (Navarro et al., 2004), indicating that puberty may be advanced by exogenous kisspeptin. In ewe lambs, intermittent injections of kisspeptin increase ovarian steroidogenesis and leads to a preovulatory surge of LH that is followed by ovulation/follicle luteinization (Redmond et al., 2011a).

Studies have implicated kisspeptin in mediating the nutritional control of reproduction. Feed restriction decreases KISS1 mRNA in the hypothalamus of prepubertal rats and kisspeptin treatment alleviates undernutrition-induced delayed puberty in female rats (Castellano et al., 2005). In addition, rats reared in small litters to allow elevated body weight gain during the prepubertal period exhibit early onset of vaginal opening, increased KISS1 expression, and greater number of kisspeptin neurons (Castellano et al., 2011). Although leptin signaling is considered important for pubertal development, the requirement for direct leptin signaling on kisspeptin neurons has been challenged recently. A study by Quennell et al. (2011) demonstrated that leptin induction of STAT3 phosphorylation, a major intracellular signaling mechanism induced by leptin, is absent in kisspeptin neurons. Furthermore, Donato et al. (2011) demonstrated that deletion of leptin receptor in kisspeptin neurons does not impair the onset of puberty in mice. Interestingly, the ventral premammillary nucleus appears to have a major role in mediating leptin's permissive effects for normal reproductive maturation in mice (Donato et al., 2011). Because the premammillary region has been involved in the seasonal control of reproduction in sheep (Malpaux et al., 1998), this hypothalamic region may serve to integrate metabolic and photoperiodic cues important for the onset of puberty in seasonal species.

It remains to be determined whether kisspeptin-independent actions of leptin on pubertal development observed in mice are conserved in other mammalian species. Nevertheless, intermediate pathways can be involved and the NPY system represents a potential candidate. Neuronal fibers containing NPY are observed in close proximity to kisspeptin neurons in sheep (Backholer et al., 2010). Recent studies in our laboratory indicated that this structural association between NPY and kisspeptin neurons may represent synaptic inputs (Figure 1; unpublished). However, 

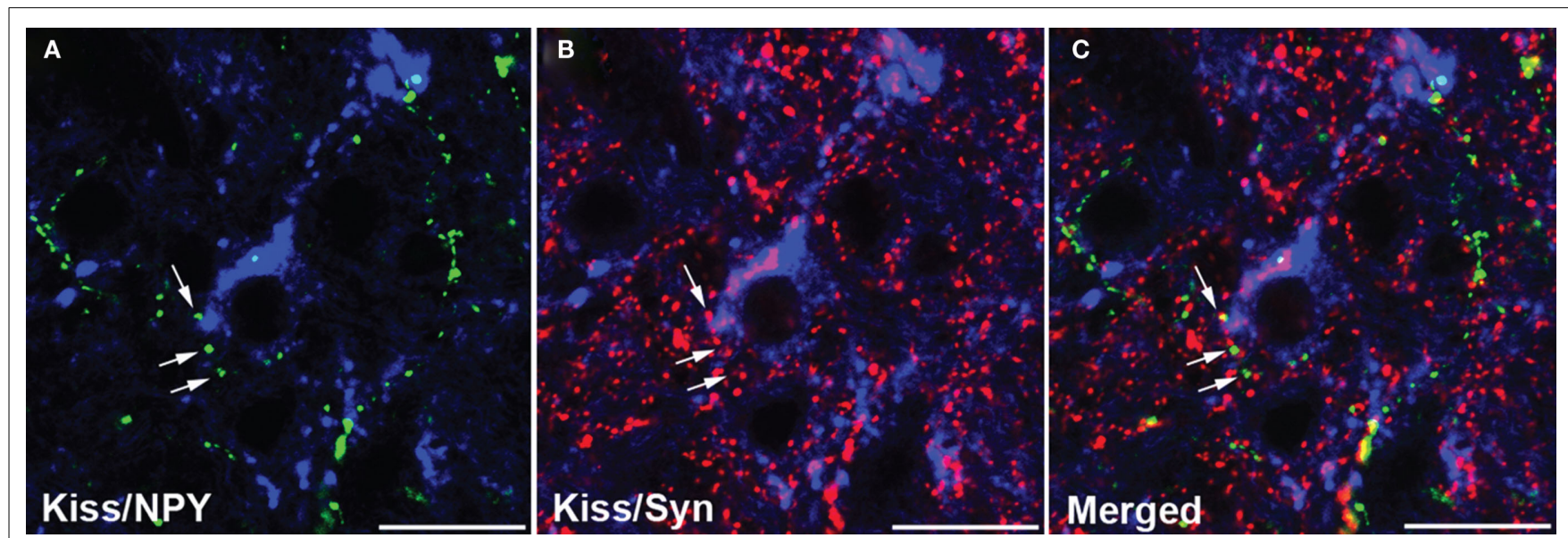

FIGURE 1 | Confocal images (1- $\mu \mathrm{m}$ optical section) of a tissue section through the arcuate nucleus processed for triple-label immunofluorescent detection of kisspeptin (Kiss), neuropeptide Y (NPY), and synaptophysin (Syn). Immunoreactive kisspeptin soma and dendrites (blue) are observed in close proximity to NPY- [gren; (A)] and synaptophysin[red; (B)] positive axons. (C) Synaptophysin colocalization in NPY axons that are in close proximity to kisspeptin neurons. Arrows indicate examples of NPY/synaptophysin-positive terminals. Scale bar, $20 \mu \mathrm{m}$. preliminary data indicated that the number of close contacts between NPY-containing fibers and kisspeptin neurons in the preoptic area and arcuate nucleus did not differ between ewe lambs fed to gain weight at high and moderate rates during the juvenile period (unpublished). Therefore, it is unclear whether regulation of the NPY-kisspeptin circuitry may contribute to mechanisms leading to the activation of kisspeptin neurons during pubertal development.

Expression of the KISS1 gene increases during puberty in mice (Han et al., 2005), rats (Navarro et al., 2004), and monkeys (Shahab et al., 2005). In juvenile rats, the increase in KISS1 expression was associated with increased frequency of LH pulses (Takase et al., 2009). In ovariectomized, estradiol-replaced ewe lambs, an increase in the number of KISS1-expressing cells is observed in the preoptic area early during the juvenile period (Redmond et al., 2011b), but these changes are unrelated to changes in the frequency of LH release. In contrast, the number of KISS1expressing cells in the arcuate nucleus increases with acceleration of pulsatile LH release characteristic of pubertal development. A recent study has questioned the relevance of kisspeptin neurons for the establishment of reproductive function in mice (Mayer and Boehm, 2011). In that study, mice with genetic ablation of kisspeptin neurons, or ablation of kisspeptin receptor in neurons during fetal development exhibited normal fertility. In contrast, ablation of kisspeptin neurons in adult mice impaired normal cyclicity (Mayer and Boehm, 2011). Therefore, compensatory mechanisms and pathways may develop during fetal development in the absence of kisspeptin neurons. Further studies should determine if the pubertal onset of high-frequency pulsatile release of $\mathrm{LH}$ involves activation of kisspeptin neurons as downstream targets of pathways integrating estradiol negative feedback and nutritional information.

\section{CONCLUSION}

The discovery of a link between excessive nutrient intake/weight gain during the infantile/juvenile period and early onset of puberty

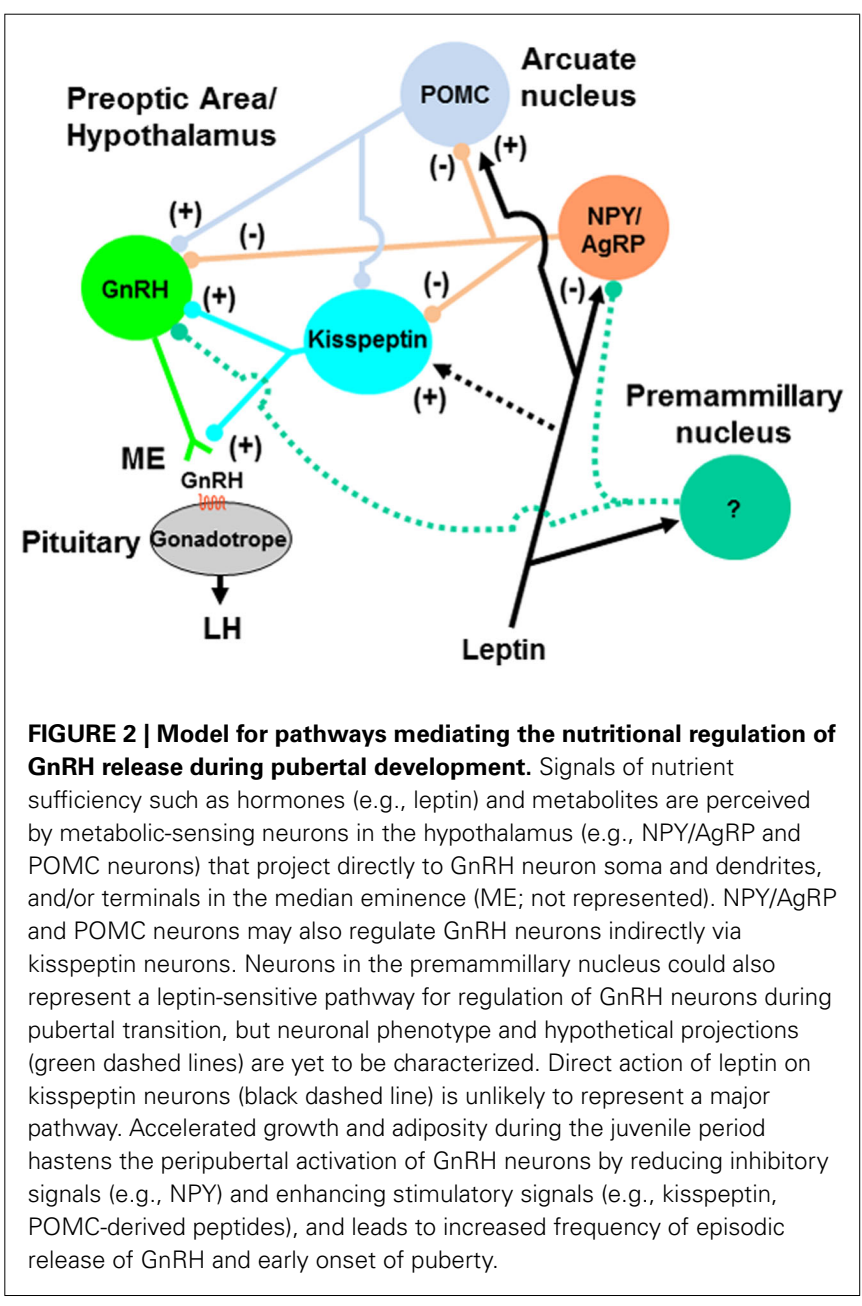

has exacerbated concerns of childhood obesity. Mechanisms mediating the nutritional acceleration of puberty involve an 
integration of metabolic sensors and effectors, largely at the hypothalamic level. Leptin is likely to be involved in this process and may signal at multiple hypothalamic and cellular targets. The NPY system is a strong candidate for mediating leptin and other nutritional/metabolic signals that influence GnRH neurosecretion in ruminants. NPY may exert its effects through direct inputs on GnRH neurons and/or indirectly via intermediate pathways such as kisspeptin neurons (Figure 2). Other cells (e.g., POMC neurons) may also be involved. Whether the premammillary region of the hypothalamus has a role in mediating leptin's effects in ruminant species, as demonstrated in mice, remains to be determined. Ultimately, hypothalamic gene expression is affected by nutritional inputs, and the regulation of

\section{REFERENCES}

Ahima, R. S., and Hileman, S. M. (2000). Postnatal regulation of hypothalamic neuropeptide expression by leptin: implications for energy balance and body weight regulation. Regul. Pept. 92, 1-7.

Ahima, R. S., Kelly, J., Elmquist, J. K., and Flier, J. S. (1999). Distinct physiologic and neuronal responses to decreased leptin and mild hyperleptinemia. Endocrinology 140, 4923-4931.

Allen, C. C., Li, X., Tedeschi, L. O., Zhou, H., Paschal, J. A., Spencer, T. E., Braga-Neto, U. M., Keisler, D. H., Amstalden, M., and Williams, G. L. (2009). Dietary treatments that facilitate early onset of puberty in heifers alter gene expression in the arcuate nucleus. Proc. Soc. Study Reprod. 81, abstr. 489.

Alves, B. R. C., Liu, S., Stevenson, E., Thorson,. J. F, Cardoso, R. D., Tedeschi, L. O., Keisler, D. H., Williams, G. L., and Amstalden, M. (2011). Accelerated body weight gain during the juvenile period reduces neuropeptide $\mathrm{Y}$ close contacts with GnRH neurons in heifers. Proc. Soc. Study Reprod. abstr. 191.

Amstalden, M., Garcia, M. R., Stanko, R. L., Nizielski, S. E., Morrison, C. D., Keisler, D. H., and Williams, G. L. (2002). Central infusion of recombinant ovine leptin normalizes plasma insulin and stimulates a novel hypersecretion of luteinizing hormone after short-term fasting in mature beef cows. Biol. Reprod. 66, 1555-1561.

Andrews, W. W., and Ojeda, S. R. (1977). On the feedback actions of estrogen on gonadotropin and prolactin release in infantile female rats. Endocrinology 101, 1517-1523.

Backholer, K., Smith, J. T., Rao, A., Pereira, A., Iqbal, J., Ogawa, S., Li, Q., and Clarke, I. J. (2010). Kisspeptin cells in the ewe brain respond to leptin and communicate with neuropeptide $\mathrm{Y}$ and proopiomelanocortin cells. Endocrinology 151, 2233-2243.

Bouret, S. G., Draper, S. J., and Simerly, R. B. (2004a). Trophic action of leptin on hypothalamic neurons that regulate feeding. Science 304, 108-110.

Bouret, S. G., Draper, S. J., and Simerly, R. B. (2004b). Formation of projection pathways from the arcuate nucleus of the hypothalamus to hypothalamic regions implicated in the neural control of feeding behavior in mice. J. Neurosci. 24, 2797-2805.

Bouret, S. G., Gorski, J. N., Patterson, C. M., Chen, S., Levin, B. E., and Simerly, R. B. (2008). Hypothalamic neural projections are permanently disrupted in dietinduced obese rats. Cell Metab. 7, 179-185.

Broberger, C., Johansen, J., Johansson, C., Schalling, M., and Hokfelt, T. (1998). The neuropeptide Y/agouti gene-related protein (AGRP) brain circuitry in normal, anorectic and monosodium glutamate-treated mice. Proc. Natl. Acad. Sci. U.S.A. 95, 15043-15048.

Caraty, A., Smith, J. T., Lomet, D., Ben Saïd, S., Morrissey, A., Cognie, J., Doughton, B., Baril, G., Briant, C., and Clarke, I. J. (2007). Kisspeptin synchronizes preovulatory surges in cyclical ewes and causes ovulation in seasonally acyclic ewes. Endocrinology 148, 5258-5267.

Castellano, J. M., Bentsen, A. H., Sánchez-Garrido, M. A., Ruiz-Pino, F., Romero, M., Garcia-Galiano, D., Aguilar, E., Pinilla, L., Diéguez, C., Mikkelsen, J. D., and Tena-Sempere, M. (2011). Early metabolic programming of puberty onset: impact of changes in postnatal feeding and rearing conditions on the timing of puberty and development

expression of a network of genes and their products affect cellular and structural functions that are critical for timing puberty in mammals.

\section{ACKNOWLEDGMENTS}

Authors would like to acknowledge Dr. Alain Caraty (INRA, France) for providing kisspeptin antiserum and Drs. Rola Mouneimne and Robert Burghardt (Texas A\&M University, USA) for their assistance with confocal microscopy. This work was supported by Agriculture and Food Research Initiative Competitive Grant no. 2009-65203-05678 from the USDA National Institute of Food and Agriculture, and National Institutes of Health Grant R03HD064761-01.

of the hypothalamic kisspeptin system. Endocrinology 152, 3396-3408.

Castellano, J. M., Navarro, V. M., Fernandez-Fernandez, R., Nogueiras, R., Tovar, S., Roa, J., Vazquez, M. J., Vigo, E., Casanueva, F. F., Aguilar, E., Pinilla, L., Dieguez, C., and Tena-Sempere, M. (2005). Changes in hypothalamic KiSS-1 system and restoration of pubertal activation of the reproductive axis by kisspeptin in undernutrition. Endocrinology 146, 3917-3925.

Catzeflies, C., Pierroz, D. D., RohnerJeanrenaud, F., Rivier, J., Sizonenko, P. C., and Aubert, M. L. (1993). Neuropeptide Y administered chronically into the lateral ventricle profoundly inhibits both the gonadotropic and the somatotropic axis in intact adult female rats. Endocrinology 132, 224-234.

Crown, A., Clifton, D. K., and Steiner, R. A. (2007). Neuropeptide signaling in the integration of metabolism and reproduction. Neuroendocrinology 86, 175-182.

Day, M. L., Imakawa, K., Garcia-Winder, M., Zalesky, D. D., Schanbacher, B. D., Kittok, R. J., and Kinder, J. E. (1984). Endocrine mechanisms of puberty in heifers: estradiol negative feedback regulation of luteinizing hormone secretion. Biol. Reprod. 31, 332-341.

de Roux, N., Genin, E., Carel, J. C., Matsuda, F., Chaussain, J. L. and Milgrom, E. (2003). Hypogonadotropic hypogonadism due to loss of function of the KiSS1derived peptide receptor GPR54. Proc. Natl. Acad. Sci. U.S.A. 100, 10972-10976.

Donato, J. Jr., Cravo, R. M., Frazão, R., Gautron, L., Scott, M. M., Lachey, J., Castro, I. A., Margatho, L. O., Lee, S., Lee, C., Richardson, J. A., Friedman, J., Chua, S. Jr., Coppari, R.,
Zigman, J. M., Elmquist, J. K., and Elias, C. F. (2011). Leptin's effect on puberty in mice is relayed by the ventral premammillary nucleus and does not require signaling in Kiss1 neurons. J. Clin. Invest. 121, 355-368.

Ebling, F. J., Kushler, R. H., and Foster, D. L. (1990). Pulsatile LH secretion during sexual maturation in the female sheep: photoperiodic regulation in the presence and absence of ovarian steroid feedback as determined in the same individual. Neuroendocrinology 52, 229-237.

El Majdoubi, M., Sahu, A., Ramaswamy, S., and Plant, T. M. (2000). Neuropeptide Y: A hypothalamic brake restraining the onset of puberty in primates. Proc. Natl. Acad. Sci. U.S.A. 97, 6179-6184.

Estrada, K. M., Pompolo, S., Morris, M. J., Tilbrook, A. J., and Clarke, I. J. (2003). Neuropeptide Y (NPY) delays the oestrogen-induced luteinizing hormone ( $\mathrm{LH})$ surge in the ovariectomized ewe: further evidence that NPY has a predominant negative effect on $\mathrm{LH}$ secretion in the ewe. J. Neuroendocrinol. 15, 1011-1020.

Foster, D. L., and Jackson, L. M. (2006). "Puberty in the sheep," in Knobil and Neill's Physiology of Reproduction, ed. J. Neill (New York/Oxford: Elsevier/Academic), 2127-2176.

Foster, D. L., and Karsch, F. J. (1975). Development of the mechanism regulating the preovulatory surge of luteinizing hormone in sheep. Endocrinology 97, 1205-1209.

Foster, D. L., and Olster, D. H. (1985). Effect of restricted nutrition on puberty in the lamb: patterns of tonic luteinizing hormone (LH) secretion and competency of the LH surge system. Endocrinology 116, 375-381. 
Foster, D. L., and Ryan, K. D. (1979). Endocrine mechanisms governing transition into adulthood: a marked decrease in inhibitory feedback action of estradiol on tonic secretion of luteinizing hormone in the lamb during puberty. Endocrinology 105, 896-904.

Foster, D. L., Ryan, K. D., and Papkoff, H. (1984). Hourly administration of luteinizing hormone induces ovulation in prepubertal female sheep. Endocrinology 115, 1179-1185.

Gasser, C. L., Bridges, G. A., Mussard, M. L., Grum, D. E., Kinder, J. E., and Day, M. L. (2006a). Induction of precocious puberty in heifers III: hastened reduction of estradiol negative feedback on secretion of luteinizing hormone. J. Anim. Sci. 84, 2050-2056.

Gasser, C. L., Grum, D. E., Mussard, M. L., Fluharty, F. L., Kinder, J. E., and Day, M. L. (2006b). Induction of precocious puberty in heifers I: enhanced secretion of luteinizing hormone. J. Anim. Sci. 84, 2035-2041.

Gazal, O. S., Leshin, L. S., Stanko, R. L., Thomas, M. G., Keisler, D. H., Anderson, L. L., and Williams, G. L. (1998). Gonadotropin-releasing hormone secretion into thirdventricle cerebrospinal fluid of cattle: correspondence with the tonic and surge release of luteinizing hormone and its tonic inhibition by suckling and neuropeptide Y. Biol. Reprod. 59, 676-683.

Golub, M. S., Collman, G. W., Foster, P. M., Kimmel, C. A., Meyts, E. R., Reiter, E. O., Sharpe, R. M., Skakkebaek, N. E., and Toppari, J. (2008). Public health implications of altered puberty timing. Pediatrics 121(Suppl. 3), S218-S230.

Han, S. K., Gottsch, M. L., Lee, K. J., Popa, S. M., Smith, J. T., Jakawich, S. K., Clifton, D. K., Steiner, R. A., and Herbison, A. E. (2005). Activation of gonadotropin-releasing hormone neurons by kisspeptin as a neuroendocrine switch for the onset of puberty. J. Neurosci. 25, 11349-11356.

Henry, B. A., Goding, J. W., Alexander, W. S., Tilbrook, A. J., Canny, B. J., Dunshea, F., Rao, A., Mansell, A., and Clarke, I. J. (1999). Central administration of leptin to ovariectomized ewes inhibits food intake without affecting the secretion of hormones from the pituitary gland: evidence for a dissociation of effects on appetite and neuroendocrine function. Endocrinology 140, 1175-1182.
I'Anson, H., Manning, J. M., Herbosa, C. G., Pelt, J., Friedman, C. R., Wood, R. I., Bucholtz, D. C., and Foster, D. L. (2000). Central inhibition of gonadotropin-releasing hormone secretion in the growthrestricted hypogonadotropic female sheep. Endocrinology 141, 520-527.

Jasik, C. B., and Lustig, R. H. (2008). Adolescent obesity and puberty: the "perfect storm." Ann. N. Y. Acad. Sci. 1135, 265-279.

Kadokawa, H., Matsui, M., Hayashi, K., Matsunaga, N., Kawashima, C., Shimizu, T., Kida, K., and Miyamoto, A. (2008). Peripheral administration of kisspeptin-10 increases plasma concentrations of $\mathrm{GH}$ as well as LH in prepubertal Holstein heifers. J. Endocrinol. 196, 331-334.

Kalra, S. P., and Crowley, W. R. (1984). Norepinephrine-like effects of neuropeptide $\mathrm{Y}$ on $\mathrm{LH}$ release in the rat. Life Sci. 35, 1173-1176.

Kalra, S. P., and Kalra, P. S. (2003). Neuropeptide Y: a physiological orexigen modulated by the feedback action of ghrelin and leptin. Endocrine 22, 49-56.

Kaplowitz, P. B., Slora, E. J., Wasserman, R. C., Pedlow, S. E., and Herman-Giddens, M. E. (2001). Earlier onset of puberty in girls: relation to increased body mass index and race. Pediatrics 108, 347-353.

Khong, K., Kurtz, S. E., Sykes, R. L., and Cone, R. D. (2001). Expression of functional melanocortin-4 receptor in the hypothalamic GT1-1 cell line. Neuroendocrinology 74, 193-201.

Kinder, J. E., Day, M. L., and Kittok, R. J. (1987). Endocrine regulation of puberty in cows and ewes. J. Reprod. Fertil. 34(Suppl.), 167-186.

Klenke, U., Constantin, S., and Wray, S. (2010). Neuropeptide Y directly inhibits neuronal activity in a subpopulation of gonadotropinreleasing hormone-1 neurons via Y1 receptors. Endocrinology 151, 2736-2746.

Lee, J. M., Appugliese, D., Kaciroti, N., Corwyn, R. F., Bradley, R. H., and Lumeng, C. J. (2007). Weight status in young girls and the onset of puberty. Pediatrics 119, e624-e630.

Maciel, M. N., Zieba, D. A., Amstalden, M., Keisler, D. H., Neves, J. P., and Williams, G. L. (2004). Leptin prevents fasting-mediated reductions in pulsatile secretion of luteinizing hormone and enhances its gonadotropin-releasing hormonemediated release in heifers. Biol. Reprod. 70, 229-235.
Malina, R. M. (1994). Physical growth and biological maturation of young athletes. Exerc. Sport Sci. Rev. 22, 389-433.

Malpaux, B., Daveau, A., MauriceMandon, F., Duarte, G., and Chemineau, P. (1998). Evidence that melatonin acts in the premammillary hypothalamic area to control reproduction in the ewe: presence of binding sites and stimulation of luteinizing hormone secretion by in situ microimplant delivery. Endocrinology 139, 1508-1516.

Manning, J. M., and Bronson, F. H. (1989). Effects of prolonged exercise on puberty and luteinizing hormone secretion in female rats. Am. J. Physiol. 257, R1359-R1364.

Mayer, C., and Boehm, U. (2011). Female reproductive maturation in the absence of kisspeptin/GPR54 signaling. Nat. Neurosci. 14, 704-710.

Morrison, C. D., Daniel, J. A., Hampton, J. H., Buff, P. R., McShane, T. M., Thomas, M. G., and Keisler, D. H. (2003). Luteinizing hormone and growth hormone secretion in ewes infused intracerebroventricularly with neuropeptide Y. Domest. Anim. Endocrinol. 24, 69-80.

Navarro, V. M., Castellano, J. M., Fernandez-Fernandez, R., Barreiro, M. L., Roa, J., Sanchez-Criado, J. E., Aguilar, E., Dieguez, C., Pinilla, L., and Tena-Sempere, M. (2004). Developmental and hormonally regulated messenger ribonucleic acid expression of KiSS-1 and its putative receptor, GPR54, in rat hypothalamus and potent luteinizing hormone-releasing activity of KiSS-1 peptide. Endocrinology 145, 4565-4574.

Plagemann, A., Harder, T., Rake, A., Waas, T., Melchior, K., Ziska, T., Rohde, W., and Dörner, G. (1999). Observations on the or exigenic hypothalamic neuropeptide Ysystem in neonatally overfed weanling rats. J. Neuroendocrinol. 11, 541-546.

Plant, T. M., and Witchel, S. F. (2006). "Puberty in nonhuman primates and humans," in Knobil and Neill's Physiology of Reproduction, ed. J. Neill (New York/Oxford: Elsevier/Academic), 2177-2230.

Pohl, C. R., de Ridder, C. M., and Plant, T. M. (1995). Gonadal and nongonadal mechanisms contribute to the prepubertal hiatus in gonadotropin secretion in the female rhesus monkey (Macaca mulatta). J. Clin. Endocrinol. Metab. 80, 2094-2101.
Pralong, F. P., Voirol, M., Giacomini, M., Gaillard, R. C., and andGrouzmann, E. (2000). Acceleration of pubertal development following central blockade of the Y1 subtype of neuropeptide Y receptors. Regul. Pept. 95, 47-52.

Quennell, J. H., Howell, C. S., Roa, J., Augustine, R. A., Grattan, D. R., and Anderson, G. M. (2011). Leptin deficiency and diet-induced obesity reduce hypothalamic kisspeptin expression in mice. Endocrinology 152, 1541-1550.

Quennell, J. H., Mulligan, A. C., Tups, A., Liu, X., Phipps, S. J., Kemp, C. J., Herbison, A. E., Grattan, D. R., and Anderson, G. M. (2009). Leptin indirectly regulates gonadotropinreleasing hormone neuronal function. Endocrinology 150, 2805-2812.

Redmond, J. S., Macedo, G. G., Velez, I. C., Caraty, A., Williams, G. L., and Amstalden, M. (2011a). Kisspeptin activates the hypothalamicadenohypophyseal-gonadal axis in prepubertal ewe lambs. Reproduction 141, 541-548.

Redmond, J. S., Baez-Sandoval, G. M., Spell, K. M., Spencer, T. E., Lents, C. A., Williams, G. L., and Amstalden, M. (2011b). Developmental changes in hypothalamic Kiss1 expression during activation of the pulsatile release of luteinising hormone in maturing ewe lambs. J. Neuroendocrinol. 23, 815-822.

Rosenfield, R. L., Lipton, R. B., and Drum, M. L. (2009). Thelarche, pubarche, and menarche attainment in children with normal and elevated body mass index. Pediatrics 123, 84-88.

Roth, C. L., Mastronardi, C., Lomniczi, A., Wright, H., Cabrera, R., Mungenast, A. E., Heger, S., Jung, H., Dubay, C., and Ojeda, S. R. (2007). Expression of a tumor-related gene network increases in the mammalian hypothalamus at the time of female puberty. Endocrinology 148, 5147-5161.

Sahu, A., Crowley, W. R., Tatemoto, K., Balasubramaniam, A., and Kalra, S. P. (1987). Effects of neuropeptide Y, NPY analog (norleucine4-NPY), galanin and neuropeptide $\mathrm{K}$ on $\mathrm{LH}$ release in ovariectomized (ovx) and ovx estrogen, progesterone-treated rats. Peptides 8, 921-926.

Schioth, H. B., Kakizaki, Y., Kohsaka, A., Suda, T., and Watanobe, $\mathrm{H}$. (2001). Agouti-related peptide prevents steroid-induced luteinizing hormone and prolactin surges in female rats. Neuroreport 12, 687-690. 
Schneider, J. E. (2004). Energy balance and reproduction. Physiol. Behav. 81, 289-317.

Schwartz, M. W., Seeley, R. J., Woods, S. C., Weigle, D. S., Campfield, L. A., Burn, P., and Baskin, D. G. (1997). Leptin increases hypothalamic pro-opiomelanocortin mRNA expression in the rostral arcuate nucleus. Diabetes 46, 2119-2123.

Seminara, S. B., Messager, S., Chatzidaki, E. E., Thresher, R. R., Acierno, J. S. Jr., Shagoury, J. K., BoAbbas, Y., Kuohung, W., Schwinof, K. M., Hendrick, A. G., Zahn, D., Dixon, J., Kaiser, U. B., Slaugenhaupt, S. A., Gusella, J. F., O'Rahilly, S., Carlton, M. B., Crowley, W. F. Jr., Aparicio, S. A., and Colledge, W. H. (2003). The GPR54 gene as a regulator of puberty. N. Engl. J. Med. 349, 1614-1627.

Shahab, M., Mastronardi, C., Seminara, S. B., Crowley, W. F., Ojeda, S. R., and Plant, T. M. (2005). Increased hypothalamic GPR54 signaling: a potential mechanism for initiation of puberty in primates. Proc. Natl. Acad. Sci. U.S.A. 102, 2129-2134.

Sisk, C. L., and Foster, D. L. (2004). The neural basis of puberty and adolescence. Nat. Neurosci. 7, 1040-1047.

Suttie, J. M., Foster, D. L., Veenvliet, B. A., Manley, T. R., and Corson, I. D. (1991). Influence of food intake but independence of body weight on puberty in female sheep. J. Reprod. Fertil. 92, 33-39.

Takase, K., Uenoyama, Y., Inoue, N., Matsui, H., Yamada, S., Shimizu, M., Homma, T., Tomikawa, J., Kanda, S., Matsumoto, H., Oka, Y., Tsukamura, H., and Maeda, K. I. (2009). Possible role of oestrogen in pubertal increase of Kiss1/kisspeptin expression in discrete hypothalamic areas of female rats. J. Neuroendocrinol.21, 527-537.

Vulliémoz, N. R., Xiao, E., Xia-Zhang, L., Wardlaw, S. L., and Ferin, M. (2005). Central infusion of agouti-related peptide suppresses pulsatile luteinizing hormone release in the ovariectomized rhesus monkey. Endocrinology 146, 784-789.

Watanobe, H., Suda, T., Wikberg, J. E., and Schiöth, H. B. (1999). Evidence that physiological levels of circulating leptin exert a stimulatory effect on luteinizing hormone and prolactin surges in rats. Biochem. Biophys. Res. Commun. 263 162-165.

Wildt, L., Marshall, G., and Knobil, E. (1980). Experimental induction of puberty in the infantile female rhesus monkey. Science 207, 1373-1375.

Zieba, D. A., Amstalden, M., and Williams, G. L. (2005). Regulatory roles of leptin in reproduction and metabolism: a comparative review. Domest. Anim. Endocrinol. 29, 166-185.

Conflict of Interest Statement: The authors declare that the research was conducted in the absence of any commercial or financial relationships that could be construed as a potential conflict of interest.

Received: 03 October 2011; accepted: 09 December 2011; published online: 27 December 2011.

Citation: Amstalden $M$, Alves BRC, Liu S, Cardoso RC and Williams GL (2011) Neuroendocrine pathways mediating nutritional acceleration of puberty: insights from ruminan models. Front. Endocrin. 2:109. doi: 10.3389/fendo.2011.00109

This article was submitted to Frontiers in Systems and Translationa Endocrinology, a specialty of Frontiers in Endocrinology.

Copyright (C) 2011 Amstalden, Alves, Liu, Cardoso and Williams. This is an openaccess article distributed under the terms of the Creative Commons Attribution Non Commercial License, which permits non-commercial use, distribution, and reproduction in other forums, provided the original authors and source are credited. 